\title{
A LITERATURA COMO PASSAGEM: REFLEXÕES EM TORNO DAS FICÇÕES EM DESASSOSSEGO
}

Lucia Helena

Toda a paisagem não está em parte nenhuma.

Fernando Pessoa*

Algumas questóes de base em que se fundamenta a literatura contemporânea surgiram da metamorfose e crítica (com o que os termos designam) de um dos ícones da modernidade, cunhado pelo romance inglês, no século XVIII: o naufrágio do protagonista do romance Robinson Crusoe (1719). O texto de Daniel Defoe encontra-se relido em 1762 no Emílio, de Rousseau e, posteriormente, em outra de suas obras, Os devaneios do caminhante solitário. Nessa intervenção, Robinson recebeu uma interpretação do genebrino que se revelou mais melancólica* do que a mitologia burguesa que o anunciou como o homem empreendedor, que emergia bem sucedido dos riscos em que se lançou por seu espírito de aventura e de acumulação de bens materiais.

O romance de Defoe, por um lado, traduzia valores históricos do individualismo, pertinentes ao estatuto da modernidade, tornada plena no século XVIII e, por outro, tematizava, ainda que sem deixar isso claro, o nível de dependência que a produção de bens circunscreveria sobre as cabeças dos que estivessem no papel desempenhado pelo indígena Sexta-Feira, no texto inglês: o de subordinado ao poder de seu "amo". Passado o impulso fundador das narrativas iluministas e românticas que elaboraram a ideologia do novo pacto contratual burguês, a literatura, mais para o final do século XIX, começa a dar mostras de importantes transformações de paradigmas em relação ao par Robinson e Sexta-Feira. Na fase da modernização intensa, desenvolvida na França e na Inglaterra de meados do século XIX e no Brasil de inícios do século XX aos anos trinta, surgiram obras que trataram dessa questão com ênfase no aspecto da crise das relações humanas entre si e, mesmo, das crises entre os homens e o contexto histórico em que se debatiam. No livro que está no prelo (Ficçôes do desassossego: fragmentos da solidão contemporânea), cuidei de apenas um momento dessa relação intensa e crítica entre a narrativa e o processo social de crise, aquela que se localiza, principalmente, no final do século XX e inícios do

* (PESSOA, Fernando. Livro do desassossego: composto por Bernardo Soares, ajudante de guarda-livros na cidade de Lisboa / Fernando Pessoa. Organização de Richard Zenith. $2^{\text {a }}$ Reimpressão. São Paulo: Companhia das Letras, 2006.)

* (Cf. HELENA, Lucia. A solidão tropical: o Brasil de Alencar e da modernidade. Porto Alegre: EDIPUCRS, 2006.) 
* (Cf. WOLLF, Francis. "Nascimento da razão, origem da crise". In: NOVAES, Adauto. (org.). A crise da razão. 2. Reimp. São Paulo: Companhia das Letras; Brasília, DF: Ministério da Cultura; Rio de Janeiro: FUNARTE, 1996: 67-82; e In: NOVAES, Adauto. (org.). A crise da razão. $2^{a}$. Reimpressão. São Paulo: Companhia das Letras; Brasília, DF: Ministério da Cultura; Rio de Janeiro: FUNARTE, 1996: 47-66.)

* (Cf. BAUMAN, Zygmunt. Modernidade líquida. Trad. Plínio Dentzien. Rio de Janeiro: Zahar, 2001; Amor líquido: sobre a fragilidade dos laços humanos. Trad. Carlos Alberto Medeiros. Rio de Janeiro: Zahar, 2004; e Vidas desperdiçadas. Trad. Carlos Alberto Medeiros. Rio de Janeiro: Zahar, 2005.) século XXI. Tais narrativas, promovem a discussão do embate entre a razão e a consciência ocidental dos riscos que a própria razão apresenta, ao não conseguir controlar a hybris que é própria dos homens e do que eles constroem. Estas duas forças se manifestam ambíguas desde que se tematizou seu surgimento, no processo de constituição do pensamento racional, no mundo grego do século $\mathrm{V}$ a.C.

Nesse sentido, a razão está comprometida, na ficção que examinamos, com a ambiguidade e a crise, duas questōes candentes que, guardadas as diferenças políticas, sociais e religiosas entre o momento que atravessamos e o universo grego do século $\mathrm{V}$ a.C., estão, também, no cerne da ambiência da modernidade líquida, essa em que vivemos, dela fazendo uma época de metamorfose de paradigmas e fronteiras. *Além da figuração dos impasses da razão com a hybris, na modernidade, um outro ponto importante examinado ao longo de nossas análises foi o das noções de transformação e metamorfose que podem ser aproximadas da metáfora-conceito da passagem, introduzida, na década de 1930-1940, pelo talento crítico de Walter Benjamin.

As leituras que empreendi em Ficçôes do desassossego: fragmentos da solidão contemporânea fincaram-se em dois eixos: um deles, conceitual; o outro, semântico. Estes dois eixos se separam apenas de forma "pedagógica", pois na realização artística torna-se impossível desligar um do outro, uma vez que a forma não se desvincula do conteúdo, antes o constitui e nele se revela. No eixo semântico, tomei a metáfora do naufrágio (do personagem Robinson Crusoé) que abre a modernidade e a correlacionei às ideias de transformação, metamorfose e passagem, não exatamente sinônimas. No segundo, elaborei o conceito de ficçôes do desassossego, com ele designando as narrativas que articulam a noção de crise e de gênero trágico.

No presente artigo, com base em uma reflexão sobre a construção do pensamento trágico e o surgimento da figura da razão no mundo clássico, pretendo jogar mais luz no horizonte sempre ambíguo de uma forma artística - as ficçôes do desassossego, ${ }^{1}$ sob a qual reuni, como já foi dito, o trabalho dos eixos semântico e categorial, antes mencionados, articulando uma reflexão que dialoga com o próprio nascedouro da razão, da crise e do pensamento trágico, para discutir, ainda que embrionariamente, o sentido da literatura como "passagem”, como veremos ao longo do ensaio. Os helenistas consultados,

\footnotetext{
${ }^{1}$ Conceituação tratada ao longo de todo o livro e, em especial, no primeiro capítulo, intitulado "O silêncio, o alarido e o cosmopolitismo".
} 
em especial Vernant, Vidal-Naquet e Francis Wolff, examinaram o mundo clássico e conceituaram a razão, a crise e o pensamento trágico de modo fundamental. Seus trabalhos fornecem base consistente para a formulação da hipótese teórica utilizada no comentário de alguns romances contemporâneos considerados neste artigo.

Francis Wolff, em "Nascimento da razão, origem da crise", examina a passagem do mítico ao racional no mundo grego clássico e sublinha que o trabalho poético ali funcionou como passagem entre a tradição mítica e a figuração da polis, com sua racionalidade ela mesma múltipla e ambígua. Apoiando-se também em estudos de Marcel Detienne, considera que o poeta arcaico:

arranca os homens e os deuses do esquecimento e lhes dá assim uma memória. [...] Cabe ao poeta dizer o que verdadeiramente foi. Sem a sua palavra, os altos feitos dos homens mergulham no não-ser; através delas eles são, tendo sempre sido. Ao contrário do que fará o historiador clássico, o poeta arcaico não busca dizer o que foi tal como pôde estabelecê-lo consultando e criticando as fontes, mas o estabelece pela escansão repetida e captadora de seu dizer, eco de todos os ditos [...]

O poeta arcaico, assim agindo, permite que uma memória se teça e interligue a comunidade, não pelo poder da história como estudo da verdade do que aconteceu na comunidade, mas como o verossímil que dá sentido à sua constituição e à de seus membros. Não fosse ambígua a tensão (que não se extingue) entre as duas ordens, a dos homens e a dos deuses, mas também a da verdade e a do engano, não haveria a falha trágica que separa o entendimento de Creonte e Antígona acerca dos ritos fúnebres devidos (ou não devidos) a Etéocles e Polinice. Entre o ethos e o daimon, ${ }^{2}$ o homem assina, em face do mundo, o compromisso da existência insegura e do devir incerto, aproximando-se de uma única certeza ingrata, a de que, entre exílios, errâncias e exclusōes, haverá de cumprir a trajetória de uma vida que só se completa com a morte.

É típico, nessa linha de raciocínio, que a razão ocidental se apresente e se estruture, historicamente, sob a forma da crise. $\mathrm{O}$ que significa dizer que, por exemplo, para Francis Wolff, o Ocidente se desenvolve sempre a partir de um fazer e refazer de crises,

\footnotetext{
${ }^{2}$ As duas expressões são aqui tomadas, resumidamente, apesar de carregarem também outras possibilidades, no sentido de caráter, aquilo que é pertinente ao desempenho dos homens (ethos) e destino, tradição, parte que nos cabe intrinsecamente (daimon), no que estamos privilegiando o entendimento de Vidal-Naquet e Jean-Pierre Vernant, em seus estudos sobre a tragédia grega e o impasse cultural de que tratam, em especial no livro Mito e tragédia na Grécia antiga.
}

* (WOLLF, Francis. "Nascimento da razão, origem da crise": 70 .) 
* (Ibidem: 69.)

* (lbidem.)

* (BORNHEIM, Gerd. "Crise da ideia da crise": 47 .) uma vez que a razão não veio substituir de maneira inteiramente uniforme o mito, mas supri-lo por intermédio de várias racionalidades, diversas e conflitantes. ${ }^{*}$ Dito de outra forma, jamais houve uma nova ordem do saber - racional - substituindo a ordem antiga - mítica. Ou seja, "o nascimento da razão foi ao mesmo tempo, e necessariamente, sua crise". "E isso é o que nos leva a romper com a ideia, ela própria mítica, de uma razão unificadora e de perceber que, diante dessa tensão, a arte trouxe uma palavra mais ampla do que outras formas de manifestação que se tornaram obcecadas pela concepção da razão como algo totalizante e unificado.

Um mundo simbólico-religioso conta com a possibilidade de, a partir da palavra do poeta arcaico e mediador, estabelecer uma nova figura de verdade. Diferentemente do entendimento que a concebe como decadência e ruptura, a crise é um fenômeno ambíguo que traz a sintomatologia da passagem da tradição para um novo e híbrido complexo cultural de renovação, que integra a potência de (re) configuração da cultura em seu bojo, assim como integra elementos metamorfoseados da tradição em conjugação com o novo.

Nessa nova configuração que é também uma re-configuração, a ruína revela-se o índice de um tipo de presença. Manifestase como a presença, em fragmento, do que, embora passado e em desintegração, não desapareceu inteiramente. Uma demonstração dessa dialética de presença e ausência na ruína-fragmento dá-se na passagem, na Grécia antiga, da tradição micênica e mítica para o mundo da racionalidade da polis, fenômeno tematizado pela tragédia grega e pelos poetas trágicos do século $\mathrm{V}$ a.C, quando uma crise política se avizinhava e viria a abalar o império grego. No seu evolver, a crise, já se disse, ${ }^{*}$ com seu grande palco, acaba por se tornar sinônima da história. Pode-se assim delimitar o problema:

Tratava-se de saber se se continuaria crendo ou se não se creria mais, se se continuaria a obedecer à tradição ou se o homem se revoltaria contra ela: se a humanidade prosseguiria os seus caminhos, confiante nos mesmos guias, ou se novos chefes a fariam mudar de rumo para conduzi-la em direção a outras terras prometidas. [...] A negação já não se mascarava, ela se expandia. A razão já não era uma sabedoria equilibrada, mas uma audácia crítica. As noções mais comumente recebidas, as do consentimento universal que provava Deus, a dos milagres, eram postas em dúvida. Relegavase o divino para céus desconhecidos e impenetráveis; o homem e somente o homem se tornava a medida de todas as coisas; ele era para si próprio sua razão de ser e o seu fim. ${ }^{*}$ 
A tematização da crise no pensamento trágico da Grécia antiga se distingue da configuração de três outras crises, historicamente deslocadas para a construção da modernidade ocidental, na passagem dos séculos XVII para o XVIII e na passagem dos séculos XIX ao XX e do XX ao XXI. Nessas etapas, apesar das suas inconfundíveis diferenças, a categoria da passagem se revela elemento fundamental. Na tragédia clássica, a passagem, como categoria do pensar, aproximando-se do efeito de mediação, anuncia a oposição tensa entre duas formas de concepção do direito, que indicariam duas diferentes visões de mundo: dikè e themis.

Segundo Benveniste, em Le vocabulaire des institutions indoeuropéennes, a dikè remete a uma justiça mais elevada da polis, acima das várias famílias, do mundo mítico (e rural), que seria representado pela palavra themis, significando o direito familiar e entre as famílias da tribo. Vernant e Vidal-Naquet dirão que a tragédia coloca em cena o embate entre essas duas formas de configurar a ideia do direito e da lei - a ancestral e a social - e tematiza o impasse e a agonia do herói diante da impossibilidade da síntese, da manutenção da ambiguidade ou da superação desse dilema. Essa oposição significaria uma forma de tratar o choque entre a Grécia micênica e dórica, a Grécia mítica dos rituais do pharmakós, e a Grécia da polis, que submete o mito à racionalidade da consciência.

No contexto da modernidade, aquela oposição entre a ideia do direito e da lei estará representada pelo modo revolucionário de ser de um novo contrato escrito, o que provocará grande alteração no mundo de base rural, que se encontrará com uma outra forma de polis: a sociedade urbana do capital e do fetichismo da mercadoria. Na modernidade líquida, ${ }^{3}$ ela revela o acirramento da ambiguidade da razão que, contendo a possibilidade da hybris, pode se transformar no antípoda de si mesma, tematizando a situação violentamente agônica de um mundo em que o abjeto e o irrepresentável se tornam um desafio à ficção diante das grandes catástrofes que, a partir do genocídio da II Grande Guerra Mundial, não têm cessado de se apresentar.

Essa figura da consciência crítica, a razão que, além de ambígua, pode tornar-se o seu contrário, foi analisada, na década de 1940, por Adorno e Horkheimer, em seu conhecido $A$ dialética

\footnotetext{
${ }^{3}$ Conferir, para entendimento da expressão e o que com ela se conceitua, o que diz Bauman (2000) acerca da modernidade líquida (tida por ele como uma das fases do capitalismo.
}

* (Apud GAGNEBIN, Jeanne Marie. "A memória dos mortais: notas para uma definição de cultura a partir de uma leitura da Odisséia". In: --- Lembrar escrever esquecer. São Paulo: Editora 34, 2006:16) 
* (Vida e época de Michael K. Trad. José Rubens Siqueira. São Paulo: Companhia das Letras, 2003.)

* (ROTH, Philip. A marca humana. Trad. Paulo Henriques Brito. São Paulo: Companhia das Letras, 2003.) do esclarecimento. E, em relação a esta obra seminal, Jeanne Marie Gagnebin, em Lembrar escrever esquecer retoma juízo anterior e, renovando-o, tece uma reflexão aguda. ${ }^{*}$ Se, por um lado, não nos parece possível recuperar, tal qual, no mundo contemporâneo, o entendimento grego da razão, é possível, todavia, captar a forma pela qual a memória daquele mundo e de seus saberes foi recebida, no início do século XXI, pela produção romanesca atual.

As fiç̧ôes do desassossego dialogam, de forma complexa e bastante mediada, com a tragédia grega; e, não é excessivo dizer, dela não derivaram diretamente. Essas ficçôes acionam a memória trágica que nos diz de uma desmedida, impregnada, hoje, da violência social na qual a promessa burguesa do modelo contratual do Iluminismo e das utopias românticas da liberdade, da igualdade e da fraternidade não está mais disponível para o sujeito burguês contemporâneo e, muito menos ainda, para os excluídos da ordem econômica do capitalismo globalizado. A formulação de verdade oriunda do projeto Iluminista se encontra em crise, como se pode constatar tanto na leitura de Vida e época de Michael K, de Coetzee (1983), como na de $A$ marca humana, de Philip Roth (2000). " Quando esses romances abordam o problema da subjetividade, eles o fazem em um patamar que recusa qualquer hipótese de localização centralizada ou centralizável da marca da identidade e da razão. Neles se encarna uma questão de fronteiras, de limites, de passagem.

O personagem Coleman Silk, protagonista de $A$ marca humana, revela-se um desafio à categoria de raça como ela fora concebida nos séculos XIX e XX, até a II Guerra Mundial. Silk (a ironia perpassa o sobrenome) é um personagem estranho, pelas características raciais muito raras de que é portador: é filho de negros, tem irmãos negros, mas carrega na face e no corpo uma "brancura" que indica um passado ancestral - o da raça negra a que pertence - que não é "lido", fisicamente, de imediato.

Em um aproveitamento irônico e crítico da ambiguidade desse corpo e da ideia de crise da razão unívoca, a "aparência" de Coleman, tomada por "verdadeira" vem contradizer uma outra "verdade" não evidente: a da ideologia do recorte racial do mundo norte-americano, no qual é negro - mesmo sendo "branco" - todo aquele que tem sangue negro em suas veias. Coleman Silk - o sobrenome "seda" já é uma forma cruel de falar de sua marca e carrega também o sema da transformação, que sugere, por sua vez, não só a sua metamorfose, mas também a do bicho da seda, ao qual remete (um casulo 
branco para um negro?) - é um negro. No entanto, Coleman é um negro que mais parece um branco e, como tal, circulou por lugares e guetos que não eram negros, sendo gradativamente, sem que dê conta disso de imediato, tomado por branco e também tomado, por vezes, por judeu, em virtude de atividades que desenvolve em certos bairros e locais reservados à prática da luta de boxe.

A marca humana de que o personagem é portador é, em si, não apenas genética e racial mas, principalmente, a da diferença e da exclusão. O inteligente recurso de Roth lembra-me uma formulação de Clarice Lispector no conto "A imitação da rosa": as rosas, que assustam Laura, reprimida mulher de Armando, modesta, doméstica e marrom, se oferecem como uma ameaça emocional para a personagem, ao serem percebidas por ela como "múltiplas no mesmo talo". O romance de Roth, ao expor a singularidade de seu personagem, põe a nu a impossibilidade do caráter unitário e sem fendas não só do personagem - o que não seria novidade - mas também e principalmente da razão, seja ela racial ou não.

A narrativa de Roth não se restringe a anunciar, banalizando-o, um mundo de relativismo. A competência do escritor vai além disso: o texto de $A$ marca humana frisa a relação estreita entre quem contempla (e nesse contemplar expõe também sua visão de mundo) e o mundo contemplado (que também não é um puro fenômeno), corroendo a ideia de uma "pura objetividade" do olhar, mostrando que o olhar é, sempre, comprometido.

Em um mundo da imagem - de bombardeio da visualização, de escolaridade precária, que encontra a barreira da leitura, e no qual não mais se dispóe de tempo e estímulo para a demorada contemplação solitária, como a fruição da leitura literária requer - trazer à baila o problema do olhar, da visão e da visualidade tem sido uma forma inteligente de as narrativas contemporâneas sublinharem o universo de carência no qual, como mercadoria, elas estão mergulhadas, e em decorrência do qual perderam o valor de pertencimento e penetração social que fora conferido às narrativas fundadoras do pacto contratual iluminista e romântico.

Como se pode ver, colocada numa perspectiva histórica, a visão trágica retomada pela narrativa de Roth é uma posição de passagem precisamente porque ela não admite como definitivo e "incontornável" o mundo da sensação empírica e do racionalismo, em aparência claro, mas na realidade confuso e ambíguo.

A esse mundo, a visão trágica que se instala na ficção de Roth opõe e expõe uma nova exigência e uma nova escala de valores. A consciên- 
* (COETZEE, J. M. Vida e época de Michael K. Trad. José Rubens Siqueira. São Paulo: Companhia das Letras, 2003; )

* Elizabeth Costello: oito palestras. Trad. José Rubens Siqueira. São Paulo: Companhia das Letras, 2004;)

*(Desonra. Trad. José Rubens Siqueira. São Paulo: Companhia das Letras, 2000.) cia trágica se manifesta inquieta, angustiada, por contrapor-se a um mundo cujos benefícios implicam não mais se aceitar a razão e a racionalidade como produtoras de um pensamento único, unidade que o sujeito trágico, que frutifica da consciência do dilema, rejeita.

J. M. Coetzee, fascinante escritor contemporâneo, nos oferece, dentre outros, três textos (Vida e época de Michael K., Elizabeth Costello (1999 e 2003) e Desonra (1999). ${ }^{*}$ nos quais alguns impasses com que se depara o mundo atual se repetem para as personagens e o narrador, e dizem respeito à questão da crise, dos limites e passagens. Criando uma provocação artística que toma a cargo discutir novas formas de representar e de conceber a literatura, para além de qualquer moda multicultural, tais textos salientam como é difícil e longo o processo de reinvenção coletiva da linguagem e da emancipação, autonomia e liberdade, fenômenos que se acionam em cumplicidade com a linguagem.

O sul-africano Coetzee trata de um processo que poderia, aparentemente, colocá-lo no caldeirão de outra moda em voga nos estudos culturais, a da discussão dos romances africanos de expressão pós-colonial. Ainda que uma parte da ficção de Coetzee pudesse ser arrolada na categoria do pós-colonial e trate da África do Sul, não é esse o aspecto envolvente de sua produção, ou seja, não é esse o âmago que atribui vigor à sua prosa poderosa.

Coetzee cuida de um processo de passagem realizado pela literatura, quando essa examina a crise da razão que orientou o expansionismo, a colonização, a escravização, a economia liberal patriarcalista e autoritária escrita na língua da exclusão, qualquer que seja o idioma que a registre. E, mais importante ainda, a ficção de Coetzee vai além de uma mensagem semântica em que reverbere a ideologia da libertação. Sua complexidade estética e conceitual requer maior apuro de interpretação.

Não é por acaso que uma tríade alegórica ganha forma nas três narrativas de Coetzee privilegiadas. Esse tríptico se realiza em torno dos temas da boca (e do lábio leporino), da oralidade e da língua, formando-se um constelado de associações riquíssimo, que reúne as três obras numa espécie de reflexão sobre um processo que aborda a crise de valores e o doloroso rito de passagem entre ordens culturais em conflito. Com esse constelado indicam-se, de modo criativo, três matrizes da sustentação cultural e material que envolve o mundo dos personagens e o caracteriza em suas necessidades básicas: 0 alimento (e, simultaneamente, o abjeto), a comunicação oral e a escrita que 
persistem, reunidos e reunindo o mundo fragmentado de personagens precários, no âmbito de uma literatura dedicada a demarcar e questionar esse horizonte parco e fronteiriço, em que a reserva do humano é confrontada com a perversão e a crueldade, as quais funcionam, simultaneamente, como forças críticas e de destruição.

Em Vida e época de Michael K, o lábio leporino da criança aponta-lhe um destino. Em Elizabeth Costello, ressalta-se o culto da oralidade, pelo intelectual Egudu, doublé de conferencista e de (digamos assim) vigarista, que se apropria indevidamente das teorias de Paul Zumthor, com elas criando um álibi de cultura e credibilidade para melhor manipular a plateia que o ouve no transatlântico de luxo em que ele e Elizabeth Costello funcionam como palestrantes. Elizabeth Costello, nesse aspecto, sublinha a "má consciência do intelectual” em um mundo marcado pela violência. Em Desonra, a questão que avulta é a do idioma em que deve ser narrada a trajetória da emancipação coletiva. Ou seja, a obra encaminha a pergunta pelo idioma com o qual os escritores devem se encarregar de melhor narrar a transformação. Ou seja, constatados os problemas, expostos os eixos em que tudo se move, na esteira da violência que reúne no pós-apartheid os descendentes dos colonizados e os descendentes de colonizadores, torna-se fundamental discutir e construir a instância de linguagem a legitimar e a ser legitimada como língua da reinvenção coletiva e da emancipação. Destaca-se, a esse respeito, uma inquietação do personagem David Lurie, de Desonra, que se mostra cada vez mais desconfiado e inquieto com a (im) propriedade de se tomar o inglês como a língua a transportar a ficção sul-africana.

Partindo da imagem do lábio leporino e chegando à da impropriedade da língua do colonizador para apresentar a África em alteridade, Coetzee ilumina renovadas formas de se trabalhar o local e o universal, a relatividade do que é histórico e transitório (a vida do homem, mortal e passageira), e a universalidade da vida dos homens, nascidos e por nascer, ao longo das histórias particulares.

De tudo isso, Coetzee faz também um modo de conceituar o que é hoje a literatura, e o que são os intelectuais, e qual é sua função (se ela ainda existe) no cenário da "modernidade líquida". Se, para esse escritor, pode-se dizer que "a minha pátria não éa minha língua”, seus romances têm fornecido boa munição para que se questionem, com novas sugestōes, outras possibilidades, estranhas às estratégias da violência e da dizimação, para se pensar a literatura 
como uma forma de passagem à difícil trajetória da emancipação. E, "se minha pátria não é a minha língua", o inglês não seria nem a língua, nem a pátria dos falantes nativos, nem a dos expatriados, exilados em seu habitat. Pode ser vista, sob outro ângulo, como a língua historicamente de passagem, a englobar um mundo arcaico perdido que só existe agora nos registros escritos da antiga memória oral e mítica, e um mundo atual, o da cultura híbrida e da escrita, impossível de ser desfeito, grafado na língua do (ex) colonizador.

Além de Coetzee e Roth, outros escritores, sobre os quais não nos vamos deter agora, como Clarice Lispector e sua $A$ hora da estrela, Ronaldo Lima Lins e o Jardim Brasil: conto, João Gilberto Noll e seus Bandoleiros, Berkeley em Belaggio, O quieto animal da esquina e Lorde, também oferecem um constelado de opções que, ainda que não sejam de mesma natureza, remetem a um ponto em comum: todos os personagens principais se inserem como figurações de um deslocamento. Macabéa não cabe no mundo em que se insere. Ela, como Michael K, parece um ser de um tempo que não há mais. Sua inocência diante do que corre a sua volta não impede, como não impede Michael $\mathrm{K}$, de percorrer uma esfera que, se não é a da cidadania, ambos privados de direitos, é a de uma resistência ética silenciosa e consistente, que emociona o leitor. Leocádio Banao, ainda que pertença a um universo pouco familiar a Macabéa e a Michael K, por ser capaz de estratégias de reflexão de que eles nem sequer podem chegar perto, revelase, como outros dois, indefeso em relação à máquina do mundo. Esta, movida por uma energia dramática, se impulsiona para além das possibilidades de Leocádio, que não pode mudá-la. A tensão contínua reserva-lhe apenas a imaginação do amor e o amor das imagens, que confluem para a imagem de mulher que ele acompanha com o olhar (também amoroso, pode-se dizer).

E, aqui, uma sintonia entre os três personagens - Leocádio, Michael K e Macabéa: em um mundo de violência, esses três personagens vislumbram - apesar de se poder conectá-los à ruína dos sonhos da modernidade e ao cenário da propalada crise das utopias plenas - a esperança, na resistência sem violência de que são capazes. A reuni-los aos personagens de João Gilberto Noll, acentua-se o aspecto de serem (e de estar) em solidão. Todos eles são solitários no desenho das metrópoles do mundo que frequentam. Sua solidão é cheia de nuances, se os comparamos entre si, mas carregada de uma mesma marca: no tempo que corre, ser homem é ser só. 
As narrativas que os examinam deixam ao leitor o osso duro de roer dessa condição, de que não se podem afastar. O espaço narrativo que os constrói é a convivência com o desassossego, essa outra forma de ser na inquietude e na angústia.

Ao longo da pesquisa sobre as ficções do desassossego, que, de início, eram apenas apreendidas pelo fio da intuição, percebi que daqueles textos advém uma proposta acerca daquilo em que consiste o próprio fazer literário, que lhes garantiu a existência como um ato de amor pela linguagem.

A questão que se apresenta é a de que a literatura, hoje, existe como passagem. E, nela, o conceito de passagem tem importância fundamental. Se, nas décadas de 1960-1970 - com a retomada e revisão do formalismo russo pelo estruturalismo e, mesmo ain$\mathrm{da}$ um pouco depois - o conceito de literariedade (com apoio em Jakobson e sua teoria das seis funçôes da linguagem) e o de intertextualidade (atribuído naquele momento ao esforço de divulgação de Julia Kristeva) formavam uma chave valorizada para o estudo do sentido da literatura, cremos que hoje, apesar do esforço didático, em $O$ demônio da teoria, de Antoine Compagnon (ele deve ser colocado entre os divulgadores, não entre os teóricos), de rever a questão da literariedade e rediscuti-la, faz-se necessário refletir sobre um outro tipo de instrumental.

Não se trata, no entanto, de "inventar" um conceito. Ele já circula, e quem o introduziu no campo da crítica foi Walter Benjamin, na década de 1930, em seus artigos sobre a poesia de Baudelaire. Não se trata nem mesmo de um conceito, mas de uma metáfora-conceito, ou seja, trata-se de uma forma sensível e arguta de olhar a literatura e as outras artes. Com a expressão, Benjamin nomeia, inicialmente, um modo de mirar e admirar a paisagem de Paris, em seus estudos sobre As flores do mal.

As "passagens" - uma obra arquitetônica, mas também tema social do cotidiano da cidade, desde as décadas de 1830-1840, ${ }^{4}$ são por ele focalizadas como vitrines cheias de mercadorias, montras que permitem apreender a materialidade do mundo e a historicidade por ela revelada. Tal como o surgimento do romance de fo-

\footnotetext{
${ }^{4} \mathrm{Na}$ edição norte-americana de "Paris, Capital of the Nineteenth Century" ([1935] 2002, p. 32), Walter Benjamin informa que muitas das arcadas - as passagens - de Paris apareceram por volta de 1839. A principal condição de seu surgimento foi o "boom" no comércio de tecidos. Foi nesse período que vieram à luz os primeiros estabelecimentos com grande estoque de mercadoria, chamadas "Lojas de novidades". Elas são as precursoras das lojas de departamento dos atuais shoppings centers.
} 
* (BENJAMIN, Walter. "Paris do Segundo Império", In: _. Charles Baudelaire: um lírico no auge do capitalismo. Obras escolhidas, volume III. $2^{\text {a }}$; ed. Trad. José Carlos Martins Barbosa, Hemerson Alves Baptista. São Paulo: Brasiliense, 1991: 30.) lhetim, gerador de alterações sociais e literárias, e engendrado por transformações econômicas, as passagens acolhem em seu bojo o reclame, a propaganda, fazendo com que o cliente se encante e, nesta sedução, se abra uma nova alma para os negócios, povoando-se os corredores por onde passam os consumidores para apreciar os artigos a serem vendidos nas lojas, que recebem uma decoração especial e atraente. Desse modo, as passagens geram um novo modo de se circular entre as ruas, entre as vitrines, em vias ocupadas por todo tipo de pessoas, agrupando a multidão, formando o aspecto da massa, outra transformação do urbanismo.

Nas passagens Baudelaire encontra o escritor, o literato, "como flâneur que se dirige à feira; pensa que é para olhar, mas, na verdade, já é para procurar um comprador". . As passagens também podem ser relacionadas, em outra dimensão, ao fragmento, às notas tomadas pelo passante, nos cafés ou a esmo. Notas que, por sua vez, podem ser focalizadas como as anotações de Benjamin para escrever e ler o livro do mundo, a partir do fascínio que sobre ele exerceu a poética baudelairiana.

Essa forma de poetar chega ao Brasil com Augusto dos Anjos, na abertura do modernismo e será peça-chave na poesia de Oswald de Andrade que, com seu "olho-câmera" e sua "Kodak excursionista" (as expressões são a ele referidas pelo crítico Haroldo de Campos), fabrica um flâneur tropical, entre o cinismo e a blague, também nos anos 1924-1928, não por influência de Benjamin, mas pela capacidade de ambos de intuir e interpretar o que estava disponível nos subterrâneos da modernidade artística.

Os modernistas vislumbravam na ideia de ruptura a possibilidade de efetivar a utopia da revolução permanente. Esta envolvia não só a crítica de uma sociedade que mostrava seus aspectos de violência a atingir grau insuportável, com a eclosão das duas guerras mundiais, mas também implicava uma busca - brusca, diga-se - de novo registro de linguagem a que denominaram vanguarda e que queria também romper com formas de dicção consideradas ultrapassadas. O que, ao contrário, se coloca hoje como elemento irradiador para novos caminhos do pensamento é, a meu ver, a ideia de passagem. A passagem estabelece novos horizontes para a questão da fronteira, do limite e da própria crise, uma vez que suplementa o radicalismo da ruptura, permitindo um contágio entre o antes e o depois, entre o velho e o novo, numa convivência tensa mas bastante mais rica do que aquela que elimina um dos termos da oposição. 
No capítulo que toca a uma provável teorização sobre as passagens, Benjamin tem sido lido com ênfase no fato de que, para ele, nas passagens se expõem mercadorias com sua sedução e de que nelas o passante é encerrado em um mundo que não é o mundo - é um espetáculo.

Ainda que parta dessa acepção, a conceituação com que estou lidando encaminha uma espessura mais ampla a esse caráter formalista e perceptual das passagens. Para além da observação das passagens focalizadas em sua fisiologia, em Benjamin elas encontram o seu cronista e o seu filósofo. Em seu artigo sobre a Paris do Segundo Império, o autor pondera que, diante da nova fisionomia moderna, o passante se sente compelido, pela convivência próxima com desconhecidos, por minutos ou até por horas a fio, a desenvolver uma forma de se libertar da impressão de insegurança e perigo que isso pode acarretar. "De fato, o mais indicado era dar às pessoas uma imagem amistosa das outras. Com isso, as fisiologias teciam, a seu modo, a fantasmagoria da vida parisiense". ${ }^{*} \mathrm{Na}$ sociedade do espetáculo, que se anunciava, o elemento ficcional invade o cotidiano, dinamizando-se o imaginário.

A literatura já foi, e tem sido em muitos momentos, uma forma de veicular a tentativa de, por via artística, colaborar para que a sociedade possa ultrapassar impasses. Mas ela pode também, além disso, ser entendida como passagem, se considerarmos o seu caráter de fronteira imprecisa (e muito difícil de se delimitar com certeza, verdade, precisão - três dos mais divulgados mitos da ciência ocidental) entre o real e o imaginário, o que lhe atesta, segundo a Estética da Recepção e do Efeito, o estatuto de "como se". Nesse sentido, a literatura pode ser concebida com uma forma trágica em si mesma, ao viver a tensão dos opostos impossíveis de serem sintetizados: produtora de um mundo agônico, ao mesmo tempo capaz de ser gerador de contrastes incompatíveis, como a utopia, o ceticismo e a aporia. Uma achega ao livro Passagens [Passagen-Werk - $O$ trabalho das passagens], de Benjamin, faz-se nesse momento fundamental para que se possa encaminhar resposta, ainda que embrionária, a uma pergunta que está "na ponta da língua": - Afinal, o que é, literalmente, passagem tal como a focalizou Walter Benjamin?

[...] Estas passagens [as arcadas], uma nova descoberta do luxo industrial, são corredores cobertos de vidro, calçados em mármore ao longo de blocos inteiros de edifícios, cujos donos se juntaram para engajar-se nesta aventura. Ao longo de ambos os lados desta calçada que recebem sua luz de cima, estão as mais elegantes lojas de mercadorias, para que tal arcada seja uma cidade, um mundo em miniatura.
* (BENJAMIN, Walter. "Paris do Segundo Império". Op. cit.: 36.)

* (BENJAMIN apud BUCK-MORSS, Susan (org.). Dialética do Olhar: Walter Benjamin e o Projeto das Passagens. Belo Horizonte: UFMG - Humanitas, 2002: 25.) 
As passagens de Paris foram construídas no início do século XIX e manifestam a força da mercadoria e o fetiche que ela cultua no que, já àquele momento, seria uma incipiente "sociedade de consumo capitalista". Em "Paris do Segundo Império", Benjamin comenta que a flânerie dificilmente poderia ter-se desenvolvido em toda a plenitude sem as galerias. Nesse mundo, o flâneur está em casa.

Segundo Rolf Tiedemann, Benjamin teria deixado o livro inacabado. Sem dúvida, das citações que nele registrou e do trabalho de reflexão que empreendeu sobre os dados coletados e a relação que manteve com os poemas de Baudelaire, Benjamin escreveu uma série de artigos que enviou a Adorno, com vista a efetivar seu exercício como pesquisador junto à Escola de Frankfurt, além de poder sobreviver materialmente e, é claro, dar curso ao projeto de pensar a modernidade. Mas não se pode garantir que os registros que nos deixou sejam apenas assim - anotações inacabadas.

Retirando de suas anotaçóes material para redigir artigos e livros, no encaminhar da parte para o todo, do fragmento para um possível todo, melhor seria dizer - como teria se comportado o autor, se tivesse sobrevivido ao holocausto? Não se pode afirmar com segurança o que teria feito alguém que não pôde fechar o que começou. Mas a maneira de composição de Benjamin já não era a do livro linear, desde a escrita de Origem do drama barroco alemão.

No prefácio gnosiológico que legou, ele nos fala da necessidade de recuperar a formatação e a inscrição das ideias sob a forma do tratado, e não do modo sistemático, de estrutura acabada que se costuma atribuir à perquirição filosófica entendida como sistema. Nietzsche experimentara uma reformulação da escrita filosófica. Benjamin também grafa sua inscrição no pensamento de maneira pessoal, dando "letra" a uma assinatura. A formulação de que o livro restou inacabado talvez seja mais uma postura interpretativa de alguns de seus leitores, dentre eles Tiedemann, do que uma declaração do próprio autor. Aliás, sobre esta obra, o "trabalho das passagens", Benjamin afirmou que ela seria uma "filosofia materialista da história", construída ela mesma como passagens, vias, caminhos (por meio de outras "passagens": citaçōes, fragmentos, memórias, comentários, recortes, anotaçōes breves, textos sobre textos sobre textos sobre textos). Benjamin começou o Passagen-Werk em 1927, e em meio a interrupçōes, em 1940, ano de sua morte, ele tinha o formato que, hoje, após sua publicação, podemos constatar.

Partindo da observação sistemática, da leitura, da coleta e da montagem e remontagem das partes assim obtidas, Benjamin pro- 
duz uma monumental seleção e colagem de fragmentos, de variada proveniência, a partir dos quais vai reler a poesia de Baudelaire, as barricadas de Paris, as exposições de pintura, os panoramas, as arcadas, a Paris capital do século XIX - e, do que ficou "pronto", sempre a partir da correlação com a poesia de Baudelaire. Teria Benjamin vindo a escrever sobre outros autores, a partir do livro das Passagens, se tivesse tido tempo, já que, infelizmente morreu durante a execução desse projeto, em suicídio provocado pelo nazismo? Não sabemos ao certo. Mas o que pôde fazer - durante o tempo de penúria nazista, com sua máquina infernal, em especial sendo ele um judeu - indica que, a partir dessa leitura em caleidoscópio, desenvolveu maior alcance para seu próprio olhar e mestria filológica. De forma iluminadora, diria adiante Pierre Missac, ele produz um discurso alado. Sua rede de reflexão é cerrada e complexa, densa, difícil muitas vezes, e enigmática para um leitor que não esteja habituado à tarefa da ruminação melancólica do colecionador obsessivo de ideias e materiais.

Sua leitura e seu modo de ler praticam o hibridismo. Benjamin monta um discurso crítico que se assemelha a um riquíssimo sistema semiológico formado de resíduos. Comporta-se como o chiffonnier - o catador de papel do poema de Baudelaire que lhe chamara a atenção. Seu material de composição do livro das Passagens é oriundo de citações retiradas de livros de procedência múltipla, como já foi dito, reunindo caricaturas, fotografias, textos de economia, ciência e outros que configuram a base material para uma reflexão a "céu aberto", digamos assim. Ou seja, uma reflexão que busca ler-e-ver \& ver-e-ler seu objeto de estudo com os instrumentos críticos que fabrica, num experimento de abstração original que já pode ser visto em $O$ drama barroco alemão.

Para atingir com maior plenitude o objetivo geral da pesquisa que fundamenta esse artigo, é indispensável articular à estratégia de leitura benjaminiana o atual processo de imbricamento que tipifica as principais ficções que integram seu corpus: o jogo entre verdade e mentira; entre discurso ensaístico, biográfico e ficcional; e entre fronteiras contamináveis. Enfim, trata-se de um conjunto de ficções em que o processo de textualização compreende uma forma incessante de contaminação e disseminação: $o$ texto sobre um texto sobre outro texto, no qual a literatura e os fragmentos que orientam sua composição revelam-se passagens.

No estudo sobre o drama lutuoso (Trauer-Spiel), Benjamin argumentava que a alegoria barroca era a forma de percepção própria 
(BUCK-MORSS, Susan (org.). Op. cit.: 220.) de uma época de desgaste, transformação social e guerra prolongada, em que o sofrimento humano e a ruína material eram matéria e forma da experiência histórica, conforme observa Susan Buck-Morss em Dialética do olhar. Em contraponto, nesta pesquisa, assumo a hipótese de que a metáfora da passagem e a alegoria do naufrágio (do sujeito burguês, da razão, dos valores iluministas e românticos, e também da significação e, na ficção contemporânea, a presença do pensamento trágico re-elaborado na produção romanesca como matéria e forma da experiência histórica da globalização e da modalidade líquida da modernidade (no sentido de Bauman) a que estamos submetidos hoje. Com esse material poderemos investigar uma possibilidade teórica que me parece interessante: no enlace com o ceticismo e o pensamento trágico, a melhor ficção contemporânea tem oferecido um manancial reflexivo bastante fértil para nos servir de antídoto à penúria do pensamento na sociedade do espetáculo, em que se transformou o embriāo focalizado por Benjamin na poética de Asflores do mal, em seu estudo sobre a flânerie, as galerias, a descoberta do luxo industrial da Paris de $1850 \mathrm{em}$ diante.

Focalizando Paris com seus caminhos cobertos de vidro e revestidos de mármore, Walter Benjamin diz, em seu artigo sobre "Paris no Segundo Império", que de ambos os lados dessas vias se estendiam os mais elegantes estabelecimentos comerciais, de modo que cada uma de tais passagens era como uma cidade, um mundo em miniatura. Hoje, esse mundo em miniatura se expandiu para além das cidades e fez declinar os centros citadinos, abrindo nichos que se repetem ao infinito, do Cairo a Dakar, de Minneapolis ao Sudão, do nordeste brasileiro ao chão africano. E em meio a esta repetição do mundo virtual da burguesia, o chão de Michael K queima os pés dos que estão descalços.

Tal como os divisamos no momento, os conceitos de fiç̧ão do desassossego e consciência trágica se articulam aos sentidos atuais da literatura, concebida ela mesma como fronteira e passagem. Com Lucien Goldmann pode-se compreender que a consciência trágica se manifesta na tensão provocada pela convivência com um mundo criado pelo individualismo racionalista, com tudo o que isso tem de positivo e negativo, mas com a vantagem de pressupor a recusa radical do pensamento único e qualquer forma unilateral de focalizar a consciência.

Ressalte-se, ainda, que a consciência trágica indica uma aliança entre formas artísticas e culturais na qual se expressa um impasse: 
há um sentido de transição, mas incompleto, já que o mundo não era ainda o que viria a ser, nem deixara de ser, completamente, o que já tinha sido. Assim pensando, percebe-se que os conceitos de pensamento trágico e o de passagem, como fundamentos da presente investigação, se imbricam e implicam. Ou seja, se a razão ocidental revela, no seu nascedouro histórico, no século $\mathrm{V}$ a.C., quando foi escrita pelos poetas arcaicos, que retém em si uma tensão, um impasse, uma ambiguidade entre ser uma e múltipla nessa unidade do diverso. Desse impasse advém importante consequência para a dinâmica do pensamento: de um lado, a consciência trágica não se coloca na dimensão do futuro, pois lhe falta o porvir, nem se aferra à dimensão do passado, pois a tensão de que se nutre ocorre no "tempo do agora"; por outro, mostra-se incompatível com a tirania e o pensamento único, problematizando-os.

Numa segunda etapa, simultânea à primeira, busquei repensar o lugar e a função da literatura na cena contemporânea, assim como sua concepção em um tempo em que a teoria da representação se revela insuficiente para dar conta do que hoje se supõe ser o literário. É preciso, quanto à questão, considerar que para um tal campo confluem múltiplas faces do pensamento e da consciência trágica, em conflito entre si, dele fazendo não mais a representação mimética de um mundo ao qual a literatura seria análoga, mas, antes, um lugar de passagem em que se encena o estado agônico da linguagem sempre em transformação. Nesse sentido, a literatura é inquietude e fragmento; um dizer entre silêncio e escrita, entre o vazio e o pleno, a ruína e a ruminação.

A essa discussão deve juntar-se uma outra, que vibra em tensão: a de que se tem, na constituição do literário, de um lado, o conceito de autonomia do processo artístico, oriundo do Romantismo de Jena; de outro, a pressuposta correlação entre o texto literário "autônomo" e sua "pendência" (termo com o qual buscamos expressar seu pendor e tendência) para com o real, pois ele se dispóe, em oblíquo, à realidade contemporânea, como uma face em contraface com a produção de massa e a sociedade do simulacro e do espetáculo, com sua cultura do vazio e do esvaziamento dos homens.

Ao longo da elaboração deste artigo, e à maneira de um estilhaço que se deslocasse, uma velha conhecida se reapresentou: a metáfora do naufrágio, que nos deu, junto com a solidão, o tema e o recorte que desenvolvemos em nosso livro $A$ solidão tropical. Se, por um lado, a metáfora do naufrágio me conduziu, naquele livro de 2006, a uma interpretação da cultura na modernidade, por ou- 
tro, o exame da subjetividade dessa cultura, também por intermédio do romance, me fez aportar no texto que agora entrego ao leitor.

Tratando da nossa agonia, da instabilidade do presente ou das perspectivas pouco claras do futuro, ainda paira, na literatura, um voto à esperança. A reflexão que ela promove vislumbra o incontornável e talvez proponha que existir vale a pena e viver e navegar é preciso, com todos os riscos e riquezas das atribulações dos homens. Os que lerem (ou os que já as conhecem) as ficçôes aqui denominadas do desassossego, mergulham em um abismo sem fundo, no qual o pensar sobre o desassossego não significa desistir, nem, muito menos, abdicar. Implica, antes de tudo, examinar os fragmentos da solidão contemporânea interpretados generosamente, pela melhor ficção que as últimas décadas produziram, na passagem do século XX ao XXI, no Brasil e lá fora.

\section{Lucia Helena}

Doutorou-se em 1983 pela UFRJ, na área de Teoria da Literatura. Fez pós-doutorado em 1989, em Literatura Comparada nos Estados Unidos, na Brown University. Ministra, com relativa constância, cursos em Universidades norte-americanas e tem atuado como conferencista nos Estados Unidos e na Europa. Atualmente é professora Titular da UFF e pesquisadora 1-A do CNPq. Dentre suas publicações, destacam-se, com prêmio nacional, Totens e tabus $d a$ modernidade brasileira; e Nem musa, nem medusa: itinerários da escrita em Clarice Lispector. Como pesquisadora 1-A do CNPq, coordena o Grupo de Estudos Nação e Narração, e nele organizou, de 2003 a 2008, seis seminários nacionais e quatro publicações, sendo três em livros e uma em CD. Publicou, em 2006, o livro $A$ solidão tropical: o Brasil da modernidade e de Alencar. Tem, no prelo, o livro Fiç̧ôes do desassossego: fragmentos da solidão contemporânea.

Palavras-chave: literatura; passagem; ficção; desassossego; modernidade líquida; Walter Benjamin.

\section{Resumo}

Este artigo trata do uso ficcional do naufrágio como metáfora em textos do século XVIII, tais como o Robinson Crusoe, de Daniel Defoe, e o Émile, de Jean-Jacques Rousseau, tanto quanto em romances contemporâneos, como $O$ náufrago (Der Untergeher), de Thomas Bernhard, como um meio para abordar as transformaçōes do pensamento iluminista em direção ao que Zygmunt Bauman chamou de "modernidade líquida". Considera os vínculos entre o ceticismo e o pensamento trágico, conectando estas ideias às criativas e decisivas acepções do conceito de passagem, esboçado por 
Walter Benjamin em seus estudos sobre a poesia de Baudelaire e, em especial, no "livro em aberto" que nos legou com as suas Passagens. Por fim, reflete sobre a metáfora-conceito "passagem" vista como uma sugestiva maneira de focalizar a literatura em nosso tempo, em especial aqueles romances que podem ser chamados de "ficçōes do desassossego".

\section{Abstract}

This essay deals with the fictional use of the shipwreck as a metaphor in eighteenth-century works, such as in Daniel Defoe's Robinson Crusoe and JeanJacques Rousseau's Emile, as well as in contemporary novels, such as Thomas Bernhard's Der Untergeher (The Shipwrecked), as a pathway to address the transformations of Enlightenment thought into what Zygmunt Bauman has called 'liquid modernity'. It considers the links between Skepticism and tragic thinking, and connects these ideas with insightful and decisive formulations by Walter Benjamin, in his work on Baudelaire's poetry and especially in his $A r$ cades project. Finally, the essay discusses the concept of "arcades" an excellent metaphor to approach literature in our time, particularly those novels that can be named "fictions of disquiet".

\section{Résumé}

Cet article traite de l'usage fictionnel du naufrage en tant que métaphore aussi bien dans des textes du XVIIIe siècle, tels que le Robinson Crusoé, de Daniel Defoe, et L'Émile, de Jean-Jacques Rousseau, que dans des romans contemporains, tels que Le Naufragé (Der Untergeher), de Thomas Bernhard, comme un moyen d'aborder les transformations de la pensée illuministe en ce que Zygmunt Bauman a nommé "la modernité liquide". Le texte prend en considération les rapports entre le scepticisme et la pensée tragique, connectant ces idées aux acceptions créatives et décisives du concept de passage, ébauché par Walter Benjamin dans ses études sur la poésie de Baudelaire et, en particulier, dans ce "livre inachevé" qu'il nous a laissé dans ses Passages. Finalement il réfléchit sur la métaphore-concept de "passage" vue comme une manière suggestive d'examiner la littérature à l'heure actuelle, surtout ces romans que l'on pourrait appeler des "fictions de l'inquiétude".
Key words: literature; arcades; fiction; disquiet; liquid modernity; Walter Benjamin.

Mots-clés: littérature; passage; fiction; inquiétude; modernité liquide; Walter Benjamin.
Recebido em 21/03/2009 Aprovado em 30/06/2009 